\title{
Investigating the Narrative Structure in the Story of Little Prince by Antoine De Saint-Exupery according to Gerard Genette's theory
}

\section{Shahen Jamal Majeed}

Department of English, College of Education and Languages, Lebanese French University, Erbil, Kurdistan Region, Iraq

Shahen683@gmail.com

\section{Saleh Jebrael Saleh}

Center of Scientific Research and Development, Nowroz University, Duhok, Kurdistan Region, Iraq

salih quchan@yahoo.com

\section{ARTICLE INFO}

\section{Article History:}

Received: 19/3/2021

Accepted: 29/4/2021

Published: Spring 2021

\section{Keywords:}

Narrative, Time, Story, Little Prince, George Genette

Doi:

10.25212/Ifu.qzj.6.2.33

\begin{abstract}
Antoine de Saint-Exupery (1900-1944) published Little Prince in 1943, the story of an actual incident, which includes a collection of notes left by Saint-Exupery from his life's experiences and thoughts. The research method is based on Gerar Genette's narrative theory. A fictional narrative is the sequence of events within the axis of time. In narration, there is a distinction between what actually happened (the content of the narrative) and how to narrate what happened (the form of the narrative). The narrator is the main character of the story. According to Genette's opinions, the narrative can be matched in the fictional world and text-based narrative because the center of orientation focuses on the characternarrator. The type of narrative is in the form of a co-narrative. The narrator is a knowledgeable narrator who controls the story. Each story is told through one or more narrators, and according to Genette, the narrator can be examined in terms of the type of narrative and narrative of events within time in the form of order, continuity and frequency. The little Prince, based on Genette's theory, has an order or few time ranges from the present to the back and front, aesthetic and artistic aspect, and the painting event has the highest frequency, and the stability of dynamics or the speed of the story has positive acceleration and, in some parts negative acceleration.
\end{abstract}




\section{QALAAI ZANISTSCIENTIFIC JOURNAL \\ A Scientific Quarterly Refereed Journal Issued by Lebanese French University - Erbil, Kurdistan, Iraq \\ Vol. (6), No (2), Spring 2021 \\ ISSN 2518-6566 (Online) - ISSN 2518-6558 (Print)}

\section{Introduction}

Fantasy is a literary genre that lies on the border between fantasy and reality, something that is real but seems imaginary or something which is imaginary, but it seems real" (Masoudi, 2008, p.35). The lexical root of fantasy is Greek. In the Webster Dictionary, the word Fantastic means the production of mental images. The literal meaning of fantasy is making something visible and giving objectivity to it. Its main Meaning and concept is imaginary desire and innovation (imaginary invention) (Sedeghi, 2006, p.20).

Imagination can be considered as the most basic feature and integral part of the fantasy. In addition to imagination, other words such as fantasy and illusion are also used in this field. In Western culture, the word fantasy in the past was used as a synonym for "imagination" and gradually, it was separated from imagination in terms of intensity, weakness or type (Burt, 2003, p.3). The fantasy imagination is not separated from reality but goes beyond it and becomes superior. The Imagination is not a solid and inanimate mass of sensory perception images but is the power to transform them. In other words, imagination is not the power to make images out of reality, it is the power to make images beyond the reality and superior to the reality" (Bashlar, 1987, p.18). Magic and impossibilities are two important characteristics in fantasy literature that drive the story. In fact, these two features complete a part of fantasy definition. The story of fantasy and illusion depicts imaginary worlds in which magical, supernatural and unreal forces advance the action of a story (Mirsadeghi, 2013, p.267). Fantasy uses magical elements. Fantasy actions cannot be measured, validated and denied by practical criteria. However, these rational criteria play a role in constructing fantasy (Mohammadi 1999, p.119). Other features of fantasy include wonder and amazement. Because of the property of paradox, fantasy should amaze the reader (Ibid: 119). Fantasy stories are based on truth and because they are imaginary and have magic and impossible elements, it does not mean that they are false. The story is not supposed to be just realistic to be a reality, but it can also be unrealistic, while in its womb reflects a reality (Mirsadeghi, 2013, p.132). Fantasy literature claims to have transcended reality, escaped from human constraints, and created superior worlds (Jackson, 2003, p.2). Fantasy, like other literary genres, has 
benefited greatly from imaginative forms. Allegory, simile, metaphor and other literary crafts are widely used in the creation of fantasy works.

Fantasy has a style of metaphor and simile. By substituting pure imagination for illusion, these works are used to describe and explain reality in such a way that in conventional human feelings and experiences do not fit into the five senses, and opinions and ideas are removed from the text. But metaphorical images carry the message that is presented (Hunt, 206, p.6).

Each story is told through one or more narrators, which in Gerar Genette's views can be investigated according to the type of narration and narration of events based on time in the form of order and arrangement, continuity and frequency. The present article tries to examine the structure of the narrative in the story of the little prince from this perspective.

\subsection{Research method}

The research method in this article is based on library tools and document investigation, and according to the main aim of the study they are analyzed and described. This study specifically focused on all text of the story of the little prince.

\subsection{Research background}

To the best of the researcher's knowledge, from the viewpoint of Gerar Genette, less research in English, if any, has been done on the structure of the narrative in Exupery's Little Prince story and this paper would be a novelty in this regard.

\section{Narration from the viewpoint of Gerar Genette}

Gerar Genette is a French literary critic, theorist, and semiotician who was born in Paris in 1930. His major reputation and influence is the structuralist study of narrative, which provides one of the most comprehensive frameworks for the analysis of narrative texts. It has been said about the narration that: narratives have been formed since human beings began to speak. The exact narration begins with human history and nowhere has there been a human being without narration (Bart, 2008, p.27). The narration of narrative is a series of events that have been figured out in several time 
periods by the characters of the story and in a range of other possible but unpredictable paths that have led to a certain outcome" (Herman, 2014, p.46). Genette defines the narrative as a representation of an event with a series of imaginary real events that are expressed in written language. (Genette, 2003, pp.4243). In other words, for Gerar Genette, the narration is the sequence of events in the womb of time that have a cause and effect and defines the theory of narration as the study of the structure and its grammar rules. Genette believes that the content of the narrative and the form of the narrative are different, and this distinction is rooted in the views of Russian formalists. Because Genette is a follower of structuralists, he has accepted the views of Russian structuralists and used them in his theories (Ibid: 12).

\section{A Summary of "The Little Prince" story}

The asteroid of Little Prince is a small planet that has three sharp volcanoes beside him and his flower. Prince, a little girl who falls in love with a rose that accidentally grows on her planet due to the bad mood of the flower, he was irritated and migrated from there because of a fight he had with his flower. He uses migratory birds to migrate from their planet and, in turn, meets with a king, a self-sufficient human, a lantern keeper, a businessman, a drinker and a geographer, each of whom is doing their job seriously and at the same time with stupidity. It is noteworthy that each of these humans is a symbol who is considered as a personality type. Eventually, the geographer encourages him to travel to Earth. The Little Prince on the Earth meets a snake, a fox, a rose garden and also the narrator, who is a pilot who, as an adult, he has not forgotten his childhood. The snake promises that help him to return to his planet, the fox asks him to tame him, and in fact, falls in love with the little prince; the narrator befriends the little prince. Finally, the little prince understands the meaning of love and on the anniversary of his arrival on Earth, he bids farewell to the Earth with the help of a poisonous snake bite and goes back to his rose that is waiting for him on planet B-612 (Zabihnia \& Yeganeh, 2012, pp.267-268). 


\section{The psychological structure in Little Prince's fantasy}

\subsection{Plot}

In the story of the little prince, the sequence of events is based on a causal relationship. In addition, all those events are made up of two layers of surface structure and deep structure. Before narrating the story of the prince's descent and the plane crash, Exupery deems it necessary as a prelude talks about the confrontation of the character of children and adults. He points to this by drawing an elephant in the belly of a boa. This event, because of a poor surface structure, looks like a ridiculous painting, and from this point of view, it has a layer of deep structure that Exupery acknowledges, adults are unrealistic. Boa snakes swallow their hank properly without chewing. Later, they can no longer move and they are sleeping during the six months they are digesting.

I thought a lot about forest adventures, in turn, I was able to draw the number one image with crayon, which was my first painting. I showed my masterpiece to the big guys and asked them if they were afraid of my painting. In response, they said, why we should be afraid? A hat does not have fear, but my painting was not the shape of a hat, it was the image of a boa digesting an elephant. That time I drew inside of the abdomen of a boa constrictor so that the adults could understand. Adults always need an explanation (Exupery, 2015, p.13).

In some parts of the story, events are expressed in both surface structure and deep through painting. Thus, the story is not just made up of text, but paintings, like serial events, are justifying events before and after that. The Little Prince consists not only of the text but also of the book's drawings which have an important role in understanding and clarifying the matter" (Sadeghian, 2010, p.82). Another example is when the little prince asks the pilot to kill a sheep for him. The pilot paints the shape of a sheep several times, but the little prince does not accept. Finally, he designs a box that has several holes. The little prince accepts the last painting because he believes the sheep is in the box. The event is also in a layer of the surface structure looks ridiculous and in the deep structure layer has a deep meaning and that children 
are not superficial like adults, and is a justification for his previous event on the painting of the Boa snake during the childhood of pilot.

I want you to draw a sheep for me, then I drew a sheep. He looked carefully and said: No! This is very lethargic. Draw another, I drew again. My friend made sweets smiles kindly said: You see ... this is not a sheep, it is a ram. It has horns. I drew another one, but it was rejected like the previous ones: this one is very old. I want a sheep that lives for a long time. At that time, with the impatience and haste I had to start dismantling the aircraft engine, this I drew this painting superficially and said: This is the box and the sheep you want is in it and I was surprised very much when I saw the face of my little referee lightened: Oh! This is exactly what I wanted (Exupery, 2015, p.18).

Another meaning that can be deduced from the events associated with the painting is that when Exupery was a six-year-old child, the adults around him did not understand the painting of the boa constrictor and the digestion of the elephant in his belly. And himself, who has become an adult man, did not take this issue seriously and when instead of the sheep draws the box and the little prince accepts, and he understands this. The plot of the story begins with the plane crash in sub-Saharan Africa. Plane crash in terms of surface structure seems normal. "In our first layer, we are facing with a typical accident that might happen to any pilot. This layer is the surface structure of the condition (Mohammadi, 1999, p.282).

Falling pilot in the middle layer means returning to oneself. In fact, falling is an excuse to find lost identity and return to oneself. At the deeper level of structure, falling of pilot in the sense of means beginning of the mystery ceremony. In the deeper layers, it is inferred that the pilot is like a seeker that goes to a place that is uninhabited. He seeks the lost meaning of the philosophy of existence. Such a confusion man needs eventual to free him from this confusion. The little prince is a phenomenon for the justification of this need of the pilot. In the surface layer, the little prince seems to be a creature made of mind and imagination that so as it is. He does not apply in the real world, but in deeper layers, it is inferred that the little prince is the lost conscience of contemporary man. 
The plot of the story of the little prince is formed based on the contradiction between the utopia of humanity and the reality in the world. The Little Prince is the human utopia that has nothing to do with the Earth and its realities. In the surface structure layer, the plot of the story ends with the death of the little prince due to being bitten by snake and in the layers of deep structure, it is a kind of exit from one place to another that shows death a superficiality phenomenon and in reality, change and transformation are along with rebirth. Death is undoubtedly the end, but the reliability is immediately followed by a new beginning. Man dies on a level of being to be able to reach another level. Death causes a sudden change in the ontological level and at the same time makes the rite of passage, just as birth or mystery (Eliyadeh, 2003, p.229). All events and incidents of the story consist of two layers of surface and deep structure, each of which justifies its previous event that examples of which were mentioned. Based on the serial events of the little prince story has taken shape in today's world by human identity. The story of the little prince includes the events that symbolize the plot; thus, the audience is able to understand free perceptions and various interpretations.

\subsection{Characters}

The Little Prince and the pilot are both the main characters in the story. The difference between the two is that the little prince is a symbolic, unreal and mysterious character who descends to Earth from another world, and the pilot is a real character who is in the real world and has gained and grown over time. "The narrator and the little prince are both protagonists, but they have major differences. If the little prince is a mysterious, extraterrestrial character, the pilot is a human who has grown and changed over time." (Farnsworth, 2005, p.16). The main characters of the story are examined based on the four details of name, adjective, appearance and dialogue:

\subsubsection{The name}

The little prince is a fictional character made up by the writer. The name chosen for him has no external application in the real world and a person with such a name is not known. The Little Prince was created from the aware and lost consciences of human that contemporary man seeks to discover. The pilot who also tells the story is 
a character who does not have a specific name. Exupery gives him a common name and calls him a pilot, and is in fact, a symbol and allegory of all humanity who are perplexed in the contemporary world.

\subsubsection{Adjective}

The little prince is an innocent boy who descends to the Earth and his ideal planet. He has an adventurous personality who seeks and discovers humans on Earth: "The fox said: You are not from here, what are you looking for? The little prince said: I am looking for people (Exupery, 2015, p.84). The pilot also crashed his plane. This is the similarity between a pilot and a little prince. Both descend from heaven to Earth. The pilot is an experienced and warrior man. The pilot in sub-Saharan Africa is a symbol of a bewildered man who has lost himself and his identity. The crash of his plane in a place without water and grass has caused him to think about issues that contemporary human beings are unaware of in the tumult of the age of technology. In fact, a plane crash means the collapse of technology in the contemporary world, while it does not seem so.

\subsubsection{Appearance}

In appearance, the pilot is like any other pilot and a real human being, but the little prince is a fictional character with an innocent and childlike appearance. He has golden hair and a yellow scarf wrapped around his neck, and the little prince's physical descriptions are calmly expressed throughout the story by other characters: Do you see those wheat fields down there? I do not eat bread and wheat is useless to me. The wheat fields do not remind me of anything, and this is unfortunate; but you have golden hair and how good it will be when you tame me because wheat is golden in color, it will remind me of you (Exupery, 1394: 86), "I opened his usual yellow scarf." (Ibid: 103).

\subsubsection{Dialogue or conversation}

Throughout the story, the conversations between the little prince and the pilot and the rest of the characters are based on conflict and questions and answers. The rose is a humanoid plant that has been identified. Exupery has created the rose as a 
dramatic character and is the main motive for the Little Prince for traveling and leaving his planet, and also rose is the Little Prince's main motive for returning to his planet. The rose is the only plant-like human character that is female. In fact, in the whole story, except for the rose, who is the friend and beloved of the little prince, the other characters are all male. The rose is an allegory of Exupery's wife, who was in love with him; however, he saw her being persecuted and unloved. His relationship with his wife Consuelo had broken down. However, he was still burning in the heat of a beloved who was ignorant of him in Europe, and the rose of the story was Conseolu, who was in secret with him (Sadr, 2005, p.9). Human characters other than the pilot and the little prince are allegories of terrestrial humans, each of which shows the character of a group of people in the real world. There is only one human being living on each planet, each with a special character that is an allegory of the human character on Earth.

a) On the first planet. On the first planet, he meets a king who sees everyone as a slave and expects others will command him. The king is a symbol of arrogant people who are fascinated by ruling and dominating humans, animals and even nature: On the first planet observes the king without a servant. Seeing the little prince, the king shouts: "Oh ...... this is a servant", and this scene is very painful, although beautiful. They are people on the Earth who do not have a throne, but they do not know themselves less than the crown princes. If they can, they command humans, and if not, they command animals, like shepherd on sheep, and horsemen on horses, mules, camels and donkeys, and if they do not have this, they command things and nature. The Earth is full of coercive rulers (Mohammadi, 1378, b: 288).

b) On the second planet. On this planet, he encounters a selfish man who is always waiting for others to praise him. He is an allegory of selfish people who want to be the most beautiful, the most well-dressed and richest human being so that others will always praise them and this is a symbol of anonymity of the mass of the people. In today's world, there are people who are constantly in disgrace to get rid of painful anonymity: on the second planet, selfish has a home. He is another face of the Earth. Every great man just wants to be himself, not an ordinary self, but the most beautiful, 
the most well-dressed, richest and smartest. Anonymity means the anonymity of the masses of people. Complications of this anonymity is an intensification of selfishness. Everyone wants to be proud of someone else to get rid of anonymous of this deadly contemporary pain. One with her dress and money, another with the beauty of her face and body, a third with a degree or his tricks. We are the selfish ones of that small planet.

c) On the third planet, on the third planet, there is a drinker. It is a form looking for meaningless and drinking. He drinks to forget his shame. Why should he be ashamed, he's human, he has lost his conscience, and he is ashamed that has forgotten the meaning of life.

d) On the fourth planet on this planet, the little prince, meets with the employer. The employer just counted. He wants to take possession of the stars by counting them. He is just looking for wealth. In fact, with this allegory, Exupery wants to show the desire and thirst of money-loving of human beings. Wealthy people want to achieve anything unattainable with wealth, even the stars. They want to obtain nature and people, and whatever they want with the money. The fourth planet is the employer planet. The employer counts. He knows himself as the owner of the stars. He has money. Here Exupery is not talking about money and factory and so on. He talks about conquering and acquiring the stars. By doing so, he wants to show the insatiable human desire for wealth without having meaning to them. Indeed, if a man reaches the stars, they will own it only for themselves and not for society. Wealthy people are under the illusion that they have money to buy everything, knowledge, honor, man and nature.

e) On the fifth planet, the little prince, sees a lamp and a lamplighter. Little prince wished he could be friends with lamplighter because he was busy with something other than himself, but he is an allegory and a symbol of human beings who only obey orders and are obedient. The fifth planet is very strange that there is only a room for a lamp and a lamplighter. 
f) On the sixth planet. The sixth planet belongs to geographers who do not move. This old man, whom Exupery portrays as a wise old man, is both wise and strange; he is a geographer, but he does not know if there is an ocean or a mountain on his planet. He does not know about nearby, but from afar, which is the Earth, he is fully aware and asks the prince to go to the Earth. The old geographer is an allegory of guided and wise people whose job is enlightening and guiding aspiring people.

The needleman and the shopkeeper are other human characters that the little prince meets on the Earth besides the pilot. The needleman has the task of controlling the movement of trains and directing people to board the train. Train passengers are parables of people who go forward aimlessly and do not know where they want to go and are oblivious to the surroundings and details. With this parable, Exupery acknowledges that children, like adults, are not oblivious to their surroundings and details. In fact, children are analytic and adults are holistic: "The little prince said, they are in a hurry. What are they looking for? The train driver doesn't know either," needleman said. They either sleep or yawn on the train. Only children press their noses against the glass. "Only the children know what they are looking for," said the little prince. (Exupery, 2015, p.92).

The shopkeeper is also a holiday for people who do useless work and think that they are useful. The shopkeeper sells the thirst quencher tablet to save people time and do more important things, but the fact is that people spend the same amount of time saved for misfortunes: "The little prince said:

Why do you sell these tablets? "To save time, experts have calculated that eating one of these tablets will save fifty-three minutes a week," said the shopkeeper. So what do they spend those fifty-three minutes on? Consume with whatever they want. The little prince said to himself: If I had a lot of fifty-three minutes, I would go to the spring gladly (Mohammadi, 1999, p.93).

The humanoid animal characters that are personified and that the little prince encounters are snake and fox. The snake has a mysterious personality: "The little prince said: Oh! I understand very well, but why do you always speak in secret? The 
snake said: I will unravel all the secrets (Exupery, 2005, p.78). In most symbols, the snake is the concept of life and revival and means the one who gives life. Hence, in some civilizations, there is one word for snake and life, Rene Guenon points out that in the Arabic word snake is even called life, which means life-giving, the principle and origin of life and he is the one who gives life (Dowir, 1997, p.51).

The fox has a symbolic personality. He is the allegory of human beings who have understood the truth of life and teach a great lesson to the little prince. "The focus of the second part of the story is on the fox who teaches the little prince a great lesson and says, 'Goodbye, and now my secret, which is very simple.' Know that you cannot see well except with the eyes of the heart. What is original is hidden from view" (Mohammadi, 1999, p.296).

Another plant character, who according to the narrator, is a small flower with only three petals, stands in the desert on the way to the little prince. The little flower is an allegory of thoughtful and lonely people who are never seen, but he also gives a valuable lesson to the little prince: "The little prince asked politely: Where are the people? "I think there are six or seven people," said flower, who had seen a caravan passing by one day. I saw those years ago. But it is not clear where they can be caught. The wind takes them away. People have no roots and are very upset about this" (Exupery, 2015, p.79). Exupery does not explicitly introduce fictional characters. With little comment and in some cases without comment, he introduces his fictional characters to the reader through the actions and behaviors they perform, and thus the audience realizes the fictional character through his actions and deeds: "I every day discovered something new from the planet from his departure and travel. All this was revealed to me as a result of my thoughts, and so it was on the third day that I became aware of the sad story of the baobab trees" (ibid, p.28), "For a long time, you had no fun other than watching the sunsets. I understood this new point on the morning of the fourth day" (Ibid. p.33).

Exupery adorns the text with imaginary inanimate objects, which are mentioned in a few cases. The painted sheep is thought to be a living being: 
"Ah! This is exactly what I wanted. Do you think this sheep needs a lot of grass?" (Ibid: 19). Well is also assumed to be a human being who sings and is alive: "The little prince laughed, turned his hand to the rope of the curtain of the wheel, and the wheel sounded like an old wind chime that sounded long after the wind had settled." The little prince said: Do you hear? We have awakened the well, and it sings" (ibid: 97).

The laughter of the stars is another living thing that has been brought to life by the inanimate objects of nature: "When you look at the night sky because I live in one of those stars and because I will laugh in one of those stars, then it will be to you that all those stars laugh. You will have stars who can laugh" (Ibid: 106).

\subsection{Viewing Angle}

In The Little Prince, the narrative is told from a first-person perspective. The narrator is also the main character of the story; that is, it is the pilot who narrates past events in the first person: "Thus, I lived alone, without anyone to talk to, until six years ago when my plane crashed in sub-Saharan Africa." (Exupery, 2015, p.15). The quality of narration in the story of the little prince, in addition to the first-person perspective, is similar to the narrative practice in the fictional world. In other words, the main character of the story, the pilot, is in charge of two works, the narrator and the actor; in such a way that the narrator is one of the main characters of the story. According to Genette's views, the world of the same story in the story is text-oriented; because the center of orientation is on the character of the narrator. Also, the way the narrator is present in the story is as co-narrative; because he narrates his own story within other stories: "If I told you these details about the star of B-612 and if I told you its number, it is for great people ... "(Ibid, p.25).

In terms of the types of narrators, the narrator is the omniscient who is aware of everything and also is an uninvited narrator that expresses his ideas and theories about the story, and the narrative style is straightforward: This did not surprise me much because he knows very well that besides the big planets such as Earth, Jupiter, Mars and Venus that each of them is named, there are hundreds of other stars and ... "(Ibid, pp.23- 24). 
George Genette believes that in first-person narratives if the narrator is one of the characters in a story who acts as a tool and everything is expressed from his mind, the greatest distance is created between the story and the narrative; that is, the presence of the narrator in the story becomes much more prominent. (Shirvani Sha'naiti, 2015, p.40). Genette's epistemology focuses on the narrator, the pilot, and the little prince is called the focalist. Since the narrator is introduced as a person who is knowledgeable and aware of everything, and he is the one who the story is in his hand, the focus is of the type of zero focus, and because the narrator is the pilot and is present in the heart of the narrative, the focus is of the internal type, so we generally encounter two types of zero and internal focus.

\section{Narrative and Time in the Little Prince}

\section{a) Order and Arrangement}

According to Gerard Genette, the story of the little prince is a reminder of a narrative that happened in the past and is told by the pilot or narrator. The author mixes art with literature by breaking the normal movement of time and leaping into the past and future. The story of the little prince, in addition to the literary work, is considered a work of art that, in some parts of the story, with the back and forth of discourse and events, gives artistic effect to work.

\section{Out-of-time (anachronism) and backwards time-range dimension (internal retrospective)}

At the end of the story, the pilot repeats the narration that has been told before, jumping to the past. This anachronism is more emphatic: "So it was no coincidence that eight days ago, in the morning, when I met you, you were alone and only a thousand miles away from the settlements. So you were going from there to your landing point?" (Exupery, 2015, p.101). The recollection of the following event, which is repetitive, has more of an artistic aspect. "The water you gave me to drink because of that wheel and that rope was like mourning and music. Remember ... how good it was" (Ibid, p.105). 
Out-of-time series (anachronism) and backwards time-range dimension (external retrospective)

When the pilot narrates the story in the present after six years, by jumping to the past and breaking the linear motion of the narrative time, he states another narrative that is not repetitive, and this kind of anachronism has an artistic aspect: "Now I have a little reliance. That is, completely. But I know he's back to his star; because at dawn the next morning, I did not see his body. "His body was not too heavy." (Ibid, p.110).

The pilot tells the little prince a story from his childhood that is related to the past and is not repetitive, thus breaking the linear motion of the storytime: "The little prince said: 'What beautifies the desert is a water well hidden in a corner.' I was sometimes surprised to discover the secret of these mysterious sparkles. When I was a little boy, I had a home in an old-fashioned house, and it was a common myth that a treasure was hidden. "Of course, no one could ever find that treasure, and maybe no one tried to find it, but that treasure made all the people of the house happy. My house had a secret in its heart." (Ibid, pp.95-96). When the pilot lifts the bucket out of the well and pours water on the little prince, by disturbing the linear movement of time, he tells a story from his past and childhood that is necessary to make the work of art beautiful: I raised the bucket to his lips, he drank water with his eyes closed. It was a water that took me to the sweetness of Christmas, it was water which was different from anything I could eat, it was water which had flowed from the night in the light of the stars, from the song of the good wheel, and from the scramble of my arms. It was a good gift for the heart. When I was a boy, the Christmas tree lights and the midnight prayer song and the sweetness of the smiles made the Christmas that I was celebrating beautiful" (ibid, p. 98).

\section{Out-of-time dynasties (aneaachronism) and forward time-range dimension (external retrospective)}

In the following cases, the normal movement of time is disturbed and the narrator tells an event that is related to the future and is told earlier than the appointed time. This leap to the future in the early part of the story seems necessary to introduce a fictional character: "I got up like a flashed man, rubbed my eyes well and looked 
carefully. My eyes fell on a wonderful man who was watching me with dignity. It was the best picture I could take from him; but my image is certainly not as beautiful as the original" (Ibid, pp.16-17).

You will look at the stars at night. My star is too small to show you its place, and that's better because my star will be one of those stars for you. Then you will love to look at all the stars, all of them will be your friends and when you are relieved, you will be happy to meet me, you will always be my friend and you will want to laugh with me and sometimes you will open your window for fun and your friends will be very surprised that you look at the sky and laugh, then you will say to them: Yes, I always laugh at seeing the stars and they will think you are crazy "and you will see that I befooled you badly." (Exupery, 1394, pp. 106-107).

It will be good, you know? ... I will look at the stars too. All the stars will be wells for me with a rusty leather and all the stars will pour water for me to drink..... Wow how interesting it will be! You will have five hundred million bells and I will have five hundred million springs" (Ibid, p.109).

\section{Out-of-time dynasties (anachronism) and forward time-range dimension (internal retrospective))}

Early in the story, the pilot tells the story of the return of the little prince, which is related to the future, earlier than scheduled, that this leap to the future and the anachronism is more artistic, and in fact, refers to the end of the story at the beginning of the story: I feel very sad from the struggle of these memories. My friend has been gone with his sheep for six years now" (Ibid, p.27). In the following cases, time is of an artistic nature, and the narrator with expression prepares the audience's mind for accepting the subject and the following events ahead of time: I know a planet where there is a red-faced man. This man has never smelled a flower, he has never looked at the stars, he has never loved anyone and he has never done anything except collecting. Every day, like you, he repeats all the time that I am a serious man! A serious man. (ibid, pp.36-37). A serious man is a reference to the employer, which is repeated in the following parts of the story: The fourth planet belonged to that employer. "This man was so busy that he did not even raise his head when the little 
prince came in. I have so much work. I am a serious man and do not spend my time with verbalizing" (Ibid, pp.59-60)

The little prince recounts the final event of the story to the pilot before biting by the snake, which, in addition to the artistic effect, prepares the audience to accept the final event of the story: "Apparently I will feel bad tonight. It is a bit like the situation of someone who wants to die, it is the same, you no longer need to come and see this situation, it is not necessary for you to bother" (Exupery, 2015, p.107).

Then at the appointed time, the event is repeated and narrated, and "that night I did not see him walk. He was gone silently. When I was able to reach him, he walked resolutely and with quick steps. He said to me: Ah! You also came! And he took my hand, but he was upset again: You did badly, you came. "You will be upset, I will apparently die, but this is not true." (Ibid, p.108).

\section{b) Continuity}

In the story of the little prince, the narrator begins the narration when he was six years old. The narrator's childhood story is told in several pages. According to Genette, devoting a short piece of text to a long time of story will be a positive acceleration (deletion), which stabilizes the dynamic stability of the story at a constant speed. From the moment the narrator tells the story of the plane crash and his acquaintance with the little prince, everything happens in eight days: "In this way, I am alone and without anyone to talk to," I lived until six years ago when my plane crashed in sub-Saharan Africa ... I had difficulty for drinking water for eight days ..." (Ibid, p.15).

Therefore, according to Genette, from this point on, the stability of the dynamic or constant speed in the story will be negatively accelerated; because the author has taken a long look at the text for a short period of the story. From Genette's point of view, minimum speed or negative acceleration is also called descriptive delay. From the time the pilot crashes to the end of the story, the narrator reduces the text speed or stability of the text with many descriptions. According to the fifth possibility of 
Genette (interruption) in the delay, there is a description that the duration of the story is zero. Examples of these descriptions are given:

Once I looked at this ghost with round eyes in surprise. Do not forget that I was somewhere, a thousand miles away from any settlement. It did not seem to me that this little man was lost or exhausted from fatigue, hunger, thirst or fear. Apparently, it bore no resemblance to the price lost in the heart of the desert a thousand miles from the settlements. Finally, when I could speak, I said to him: Hey, what are you doing here? (Ibid, p.17)

In the same way, I understood the second thing that was very important, and that is, the little prince's star is a little bigger than a normal house. This did not come as a surprise to me, as I knew that there were hundreds of other stars besides the large planets of Earth, Jupiter, Mars, and Venus, each of which they named, and I have strong reasons for this theory. The planet that the little prince came from is Planet B612 , and if I told you these details about the star 612 , and if I told you its number. (Ibid: 25, 24).

Therefore, according to Genette's five possibilities, the beginning of the narrator's childhood narrative, which has positive acceleration, is the first possibility (summary); that is, the duration of the discourse is shorter than the duration of the story. From the time the pilot crashes to the end of the story, Genette's fourth possibility (elongation) is considered; because the duration of the discourse is longer than the duration of the story; That is, the time of discourse is longer than the time of the story.

\section{c) Repetition or frequency}

One of the most important and basic events of the story that conveys the concepts and promotes the plot of the story is the event of painting the pilot. This event is so important that the story begins and ends with it. The importance of the pictures and drawings is such that the author himself draws them and explains about each one. Accordingly, it has the highest frequency in the story; because children are very interested in painting, and the author expresses some concepts in the deep layers of 
storytelling in this way. For example, only a few are mentioned. The rest of the events, in addition to the surface structure layers and the apparent meaning, are also composed of deep layers of structure and deep meaning, which can be interpreted from various aspects. This aspect of the story is noteworthy in terms of aesthetics, art and literature. The following events, according to four types of frequency in Gerard Genette's views, are repetitive and include the third category; because several discourse representations of a moment are similar to a story, examples of which are given:

\section{Boa snake painting event}

But my painting was not the shape of a hat, it was the image of a boa constrictor that digested an elephant. "At that time, I drew a stomach of boa constrictor so that adults could understand" (Exupery, 2015, p.14).

Since I had never drawn a sheep, I knew one of the two pictures; I mean, I drew the closed boa constrictor for him and I was surprised when I heard that, the man replied: No, no! I do not want an elephant in the belly of a boa constrictor (Ibid, p.18).

It is very difficult for a person in my age to return to painting when at the age of six he only had drawn the shape of a closed boa constrictor and an open boa constrictor" (Ibid, p.27).

\section{The event of clapping of the little prince and his greeting on selfish-man planet}

"Selfish-man advised him to clap, the little prince clapped. Selfish with humility, picked up the hat and greeted. The little prince said to himself, this meeting is more interesting than meeting the king, and began to clapping again. Selfish also resumed greeting by lifting his hat. After five minutes of training, the little prince got tired of the monotony of the game and ..." (Ibid, pp.W55-57).

\section{The event of turning on and off the lantern by lamplighter}

The little prince greeted lamplighter as soon as he entered the planet and said:

Good day sir, why did you turn off the lantern? 
Lamplighter replied: It is an order, sir. Good Day.

What is an order?

The command is to turn off my lantern. Good night.

And he turned on the lantern again. So why did you turn it on again? Lamplighter replied: It is an order. "I do not understand," said the little prince.

Lamplighter said: "he does not understand. The command is the command. Good day and he turned off his lantern again and ..." (Ibid, p.66).

Painting the scene of the little prince ascending to his planet: This is the most beautiful and saddest scene in the world for me. This is the same scene as the previous page, but I drew it again to show you well, this is where the little prince appeared on Earth and then disappeared (Ibid, p.13).

Watching the sunset is an event that happens once in the whole story and is not repeated, and in some cases, it is only mentioned and not repeated. According to Gerard Genette's frequency types, this event is of the first category; because it is the kind of solitude that has a discourse representation of a separate moment in the story. So you were very upset on the day you watched the sunset forty-three times? But the little prince did not answer (Ibid, p.35).

"I wanted to watch the sunset once," said the little prince. Please let the sunset. The king said, "Everyone must be asked to do something." (ibid, p.51).

What the little prince did not dare to admit to himself was that he missed this auspicious planet, especially since it had one thousand four hundred and forty sunsets in twenty-four hours (Ibid, p.68).

Little Prince Laughing Event: The Little Prince: Then you will tell them that yes, I always laugh at seeing the stars and they will think you are crazy and you will see that I have befooled you and you laughed again (Ibid, p.107). 
Little Prince: It would be just like that instead of a star I'm giving you small bells that know how to laugh, and laughed again (Ibid, p.107).

\section{Conclusion}

The narrative has a long history. According to Genette, the sequence of events has a causal relationship that occurs in the heart of time. The quality of the narration in the story of the Little Prince is a direct narration and the narrator is omniscient and aware of everything, as well as the intrusive (uninvited) narrator who expresses his ideas and opinions about the story and is expressed from a first-person perspective. In Genette's views, the act of narration in the same fictional world is the same (the narrator is the main character of the story) and the center of orientation is focused on the narrator (pilot) character. Thus, the narrative style is textual. Based on Gerard Genette's views, within the story, the narrator narrates his anecdote too, which is a co-narrative. The focal point is the narrator (pilot), and the little prince has become the focal point. Its type, according to Genette, is zero, and because the narrator is one of the main characters in the story, it is an internal focus.

According to Genette's views, time in the story of the little prince is as follows: (Order): The series of out-of-time or anachronism events of the retrospective and futuristic type in the story can be studied aesthetically and artistically. (Continuity): According to Genette's five possibilities, the beginning of the narrator's childhood narrative is Genette's first possibility (summary), and the dynamic stability or constant speed of the story has positive acceleration. From the time the pilot crashes until the end of the story, there is a fourth possibility of Genette (elongation) that has a negative acceleration of dynamic stability at the story's constant speed. (Frequency or repetition): The pilot drawing event has the most frequency or repetition. The story of the little prince has two main characters (pilot and little prince), one of whom is an adult. The plot follows the causal relationship and the coherence of the relationship between the events is observed. 


\section{QALAAI ZANISTSCIENTIFIC JOURNAL}

A Scientific Quarterly Refereed Journal Issued by Lebanese French University - Erbil, Kurdistan, Iraq

Vol. (6), No (2), Spring 2021

ISSN 2518-6566 (Online) - ISSN 2518-6558 (Print)

\section{References:}

Bart, R. (2008). Introduction to the structural analysis of narrative texts. French semiotics. From structuralism to post-structuralism, 196-239.

Bashlar, G. (1987). Fire Psychoanalysis. Translated by Jalal Sattari, first edition, Tehran: Toos.

Bert, R. (2003) Imagination. Translated by Masoud Jafari, second edition, Tehran: Center.

Eliyadeh, M. (2003). Myth, Dream and Mystery. Translated by Roya Monjem, third edition, Tehran: Alam.

Exupery, A. (2015). The Little Prince, translated by Mohammad Ghazi, Tehran: Amir Kabir.

Farnsworth, R., D. (2005). The Main Components of the Little Prince. Cultural and Art Monthly 4(21). 16-27.

Genette. G. (2003). The Boundaries of Narrative (Part I). Poétique, 6(2), 131-139.

Herman, D. (2014). Fundamental Elements in Narrative Theories. Translated by Hossein Safi, first edition, Tehran: Ney.

Hunt, P. (2006). Children's Literature. Routledge: London and Newyork.

Jackson, R. (2003). The Literature of subversion, London: Routledge.

Mirsadeghi, J. (2013). Imaginary stories. First edition. Tehran. Sokhan.

Mohammadi, M. (1999a). Fantasy in Children's Literature. Tehran: Roozgar

Mohammadi, M. (1999b). Methodology of Criticism of Children's Literature. First Edition, Tehran: Soroush.

Masoudi, S. (2008). Introduction to Fantasy. First Edition, Tehran: Show Association.

Sadeghian, S. (2010). Comparative study of five translations of The Little Prince in Persian. LJE. 5(41), pp. 78-82.

Sadr, H. (2005). Love is deadly. Cultural and Art Monthly, third year, (21), 8-10. 


\section{QALAAI ZANISTSCIENTIFIC JOURNAL}

A Scientific Quarterly Refereed Journal Issued by Lebanese French University - Erbil, Kurdistan, Iraq

Vol. (6), No (2), Spring 2021

ISSN 2518-6566 (Online) - ISSN 2518-6558 (Print)

Sedighi, A. (2006). Fantasy in the Shahnameh. First Edition, Tehran: Trick.

Zabihnia O. A., \& Yeganeh M. H. (2012). History of Children and Adolescent Literature in the World. First Edition, Yazd: Hooman.

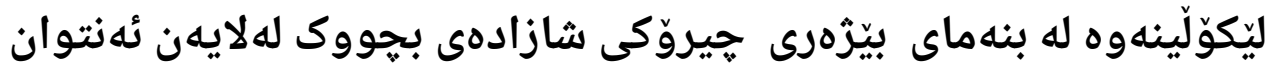
دوسانت ئهكزوبيرى بهيِّى تيوّرى جيّرارد جينيّت

ئهنتوان دوسانت نئكزوبيرى( ..19-عع19) شازادهى بجووكى له بع19 بلّاوكردهوه كه جيروّكيّكى رووداوى رِاسته قينهيه و كوّمهلَه خهسلّهتيكى تيّدايه كه سانت ئوكزبيرى لهئهزمونى زيانى خوّييهوه ورمى گرتوهو.

شيّوازى ئهم تويّزينهوهيه يشت دهبهستيّى به تيّوّرى (جيرار جنيت)و جيروّكبيزيَّكى خهيالّى له

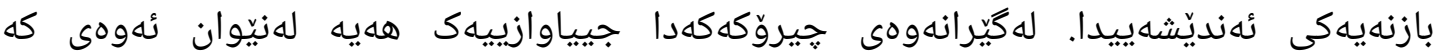

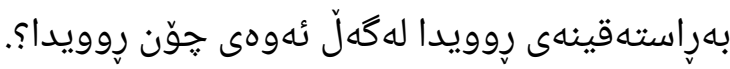
جيروّك بيّزهكه كارهكتهريّكى سهرهكييه له شازادهى بجووك و بهيِيى تيووّى جنيت دهتوانري

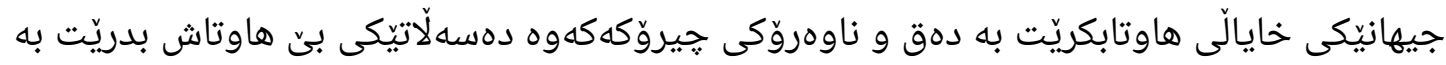
جيروّك بيّزهكه.

جيروّكى شازادهى بجووك دهكيّردريّتهوه لهلايهن يهك يان دوو بيّزهر ، بهيِّى بوّجوونى جنيت

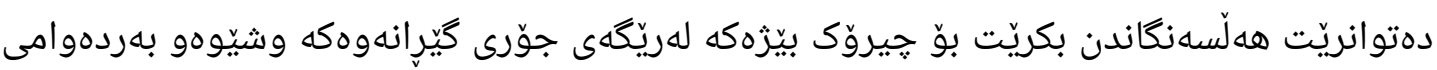
ناوه شازادهى بجووك هاوشيّوهيهكى كاتى و بجووكى ههيه لهئيسِتاو رابردوو و داهاتو. بهشيّوهيهكى كشتى ئاراسته هوونهرييهكه و خيّراييهكى ههردوولايهنى ئهرينى و نهرينى ههيه بهو يِييهى

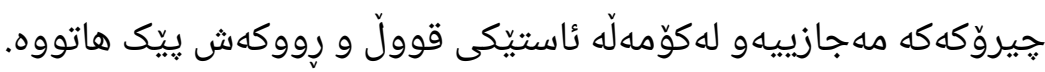




\section{QALAAI ZANISTSCIENTIFIC JOURNAL}

A Scientific Quarterly Refereed Journal Issued by Lebanese French University - Erbil, Kurdistan, Iraq

Vol. (6), No (2), Spring 2021

ISSN 2518-6566 (Online) - ISSN 2518-6558 (Print)

كارهكتهره سهرهكييهكان لهم جيروّكها يِيّكهاتوه له فروّكهوانيّك له گهل شازادهيهكى بجووك.

\section{التحقيق في البنية السردية في قصة الأمير الصغير بقلم أنطوان دو سان إكزوبيري وفقًا لتظرية جيرارد جينيت}

الملخص:

نشر أنطوان دو سانت إكزوبيري (1900-1944) الأمير الصغير في عام 1943 ، قصنة حادثة حقيقية

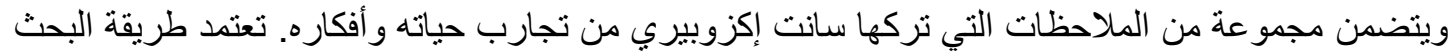

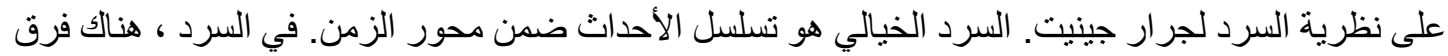

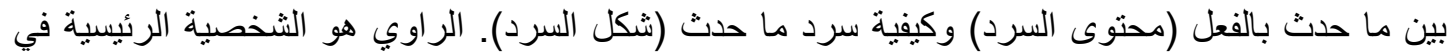

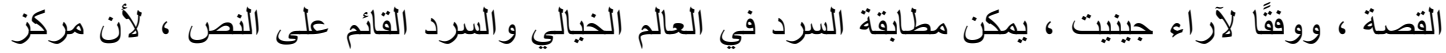

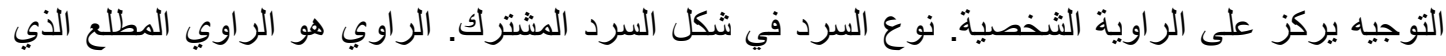

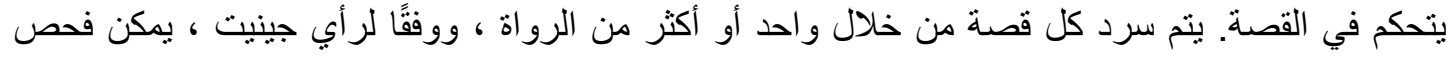

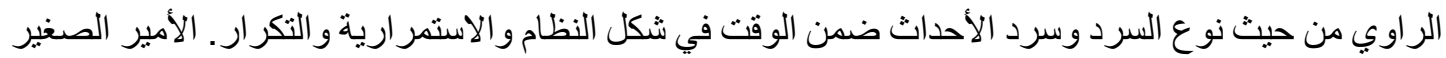

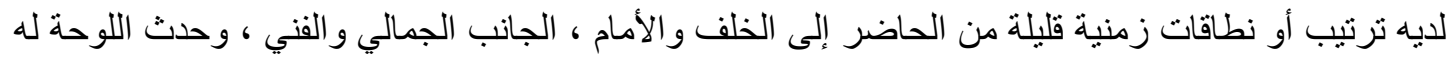

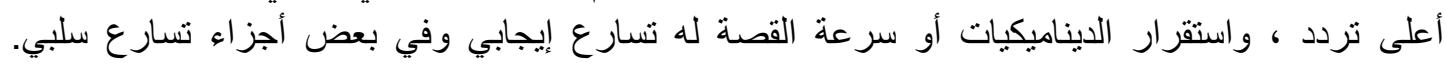

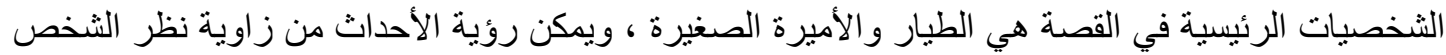
الأول وزاوية رؤية الراوي. قصة الأمير الصغير هي قصة مجازية تتكون من طبقات عميقة وكذلك سطحية 